\title{
Land Use / Land Cover Change And Impact On Carbon Stocks In The Atacora Chain Of Mountains, A Biodiversity Hotspot In Benin (West Africa)
}

\author{
Fidèle Tchossi Moutouama ${ }^{1 *}$ Boateng Kyereh ${ }^{1}$ Winston A. Asante ${ }^{1}$ Samadori Sorotori Honoré Biaou ${ }^{2}$ \\ Andrew P. Rayburn ${ }^{3}$ Armand K. Natta ${ }^{2}$ \\ 1. Kwame Nkrumah University of Science and Technology, Kumasi, Ghana, University Post Office \\ 2. University of Parakou, 03 BP 125 Parakou, Benin \\ 3. Independent Consulting Ecologist Arvada, CO 80004 USA \\ * E-mail of the corresponding author: fidelemoutouama@gmail.com
}

The research is financed by Project Niche/196/ Univesité de Parakou, CINOP, Nuffic

\begin{abstract}
Mountain areas are fragile ecosystems that play important roles in people's livelihoods and maintenance of the global ecosystem through the provision of many ecosystem services. Land use/cover (LULC) change is considered one of the major threats to mountain areas due to its effects on ecosystem services including carbon stocks. In this study we assessed LULC change between 1987 and 2015 and its impact on aboveground carbon stocks in the Atacora Chain of Mountains (ACM) in Benin, West Africa. Supervised classification was performed to delineate LULC classes on three dates (1987, 2001 and 2015), and forest measurements carried out in the land cover classes, to estimate the aboveground biomass and the subsequent carbon stocks. Seven land cover classes were delineated: gallery forests, woodlands, savanna, water, settlements, bare lands and farm lands. LULC changes were characterized by three transitions: 1) the change of man-made land cover into savanna, 2) the change of natural vegetation into man-made land cover and 3) the degradation of gallery forests and woodland into less wooded vegetation. The aboveground carbon stock in gallery forests, woodland and tree savanna were significantly greater than in shrub savanna. During the 28 years of assessment, LULC change in gallery forests, woodland and savanna caused an estimated overall aboveground carbon release of $17.10 \%$ in the ACM. From the aboveground carbon quantity in the ACM, it appeared that this ecosystem is a potential carbon reservoir. Because the aboveground carbon stock in shrub savanna is significantly lower as compared to gallery forests, woodland and tree savanna and the rates of degradation from gallery forests and woodland to savanna are high, 53.62\% and 59.99\% respectively in 28 years, LULC change may undermine the ACM ability to store carbon and contribute to climate change mitigation. There is a need to investigate the drivers of this degradation for actions to preserve the natural vegetation in the ACM.
\end{abstract}

Keywords: Atacora Chain of Mountains; Land use/land cover (LULC); Benin; West Africa; Carbon stock

DOI: $10.7176 / \mathrm{JEES} / 10-6-13$

Publication date:June $30^{\text {th }} 2020$

\section{Introduction}

Mountainous areas are increasingly at the center of global policy debates, and their importance is underlined by the fact that they host half of all 34 global biodiversity hotspots (Chape et al., 2008) and twenty percent of the world's human population lives in mountains or at their edges (Korner and Ohsawa, 2005). A wide range of factors cause mountainous areas to have high plant species diversity, including the compression of climatic zones over short distances (resulting from the effect of altitude on temperature and other climatic factors) and the high habitat heterogeneity resulting from topographic diversity driven by the forces of gravity and moderate disturbances such as landslides, avalanches and fires. Other factors include habitat isolation and fragmentation leading to local or regional diversification and use of mountainous areas as migratory corridor and grazing by large herbivores (Spehn et al., 2010). Mountains play an important role in influencing global and regional climates and weather conditions (FAO, 2011). As a major ecosystem representing the complex and interrelated ecology of the planet, mountain environments are essential to the survival of the global ecosystem (UNCED, 1992). One of the key functions of mountainous areas in the global ecosystem is their contribution to carbon cycle, a major concern of current global policy debates. With 28 percent of the world's forests, mountainous areas have huge potential for carbon storage and sequestration (FAO, 2011). According to the Millennium Ecosystem Assessment (MEA, 2005), it is very likely 
that about half of the global mountain areas is under some sort of human land use (assuming that unvegetated or bare lands and wetlands and other water bodies, which together amount $14 \%$ of the global mountain area, are mostly unaffected by humans). The depletion of natural resources in the easily accessible ecosystems of lowlands causes an increasing interest in mountain lands' resources. Consequently, considerable changes are taking place in mountain forests. Yet, mountains are highly vulnerable to human and natural ecological imbalance (UNCED, 1992) and the fragility of mountains resides in the fact that the impacts of unsustainable development are rapid, heavier and more difficult to correct than in other areas of the globe (FAO, 2000). Anthropogenic pressure associated with human settlements in and below the montane belts, land use, land transformation, and other human activities may endanger mountain biota more than climate change in many regions of the world (Korner and Ohsawa, 2006).

Atacora Chain of Mountains (ACM) is a biodiversity hotspot in northwest Benin, West Africa. ACM is the Benin portion of a range of mountains which crosses Togo and reaches Ghana. It is in the department of Atacora and oriented NNE-SSW with altitudes ranging from 300 to $650 \mathrm{~m}$ (Sinsin and Kampmann, 2010). The range of mountains helps regulates climate, hosts a diversity of plant and animal species (Wala and Sinsin, 2010) and serves as source of many rivers (INSAE, 2004). With a very closed vegetation in some areas, the ACM also has a high potential for carbon storage but is so far exploited without any consideration of its outstanding status. The ACM is a mosaic of semi-natural and man-made land cover classes which faces two major forces, climate change and population growth leading to significant changes in land use. Land clearing for agriculture, over-grazing, forest exploitation and wildfires are activities that threaten the integrity of the ACM (Sinsin and Kampmann, 2010). The population around the ACM has a high growth rate (3.06\%) with 79\% of the people engaged in the primary sector (INSAE, 2018), characterized by agriculture and natural resource exploitation. Yet, fragmentary, incoherent and poorly planned development efforts coupled with weak or non-existent management mechanisms at local levels render natural resources in mountainous areas outside protected areas particularly vulnerable (Alweny et al., 2014). Land use change that affects vegetation cover impacts carbon storage, a critical ecosystem service. Land degradation (often resulting from land use) increases emissions through the direct loss of stored carbon in soils and biomass, and the reduction of a site's potential to store carbon (FAO et al., 2011). In an era of climate change marked by the increasing requirement for countries to comply with international rules to tackle issues linked to carbon emission, monitoring of activities that emit carbon should be a research priority. At the landscape level, quantifying land cover changes provides equivalent changes in carbon stock, which is useful for estimating carbon emission and sequestration. In this study we investigated land cover dynamics in the ACM and their impact on carbon stocks.

\section{Materials and methods}

\subsection{Study area}

The study was carried out in the ACM and its surrounding areas based on the delimitation of the Biodiversity Atlas of West Africa (Sinsin and Kampmann, 2010), (Figure 1). It lies between $1^{\circ} 00^{\prime}$ and $2^{\circ} 00^{\prime}$ East longitude and $10^{\circ} 40^{\prime}$ and $11^{\circ} 28^{\prime}$ North latitudes. The ACM has a tropical climate of a Sudanian type with one dry season (November to April) and one rainy season (April to October). Annual rainfall in the area ranges from 800 to $1200 \mathrm{~mm}$ but reaches $1350 \mathrm{~mm}$ for some years due to the orographic effect. The dry season is marked by the phenomenon of harmattan, the north-easterly dry and hot wind blowing from the Sahara. The topography of the mountain chain includes hilltops and plateaus, valleys, and hillsides with steep slopes (30-60\%) (Avohou and Sinsin, 2009). The range of mountains crosses six municipalities, Natitingou, Toucoutouna, Tanguieta, Kerou, Kouande and Boukoumbe and comprises part of the Pendjari Biosphere Reserve (PBR). 


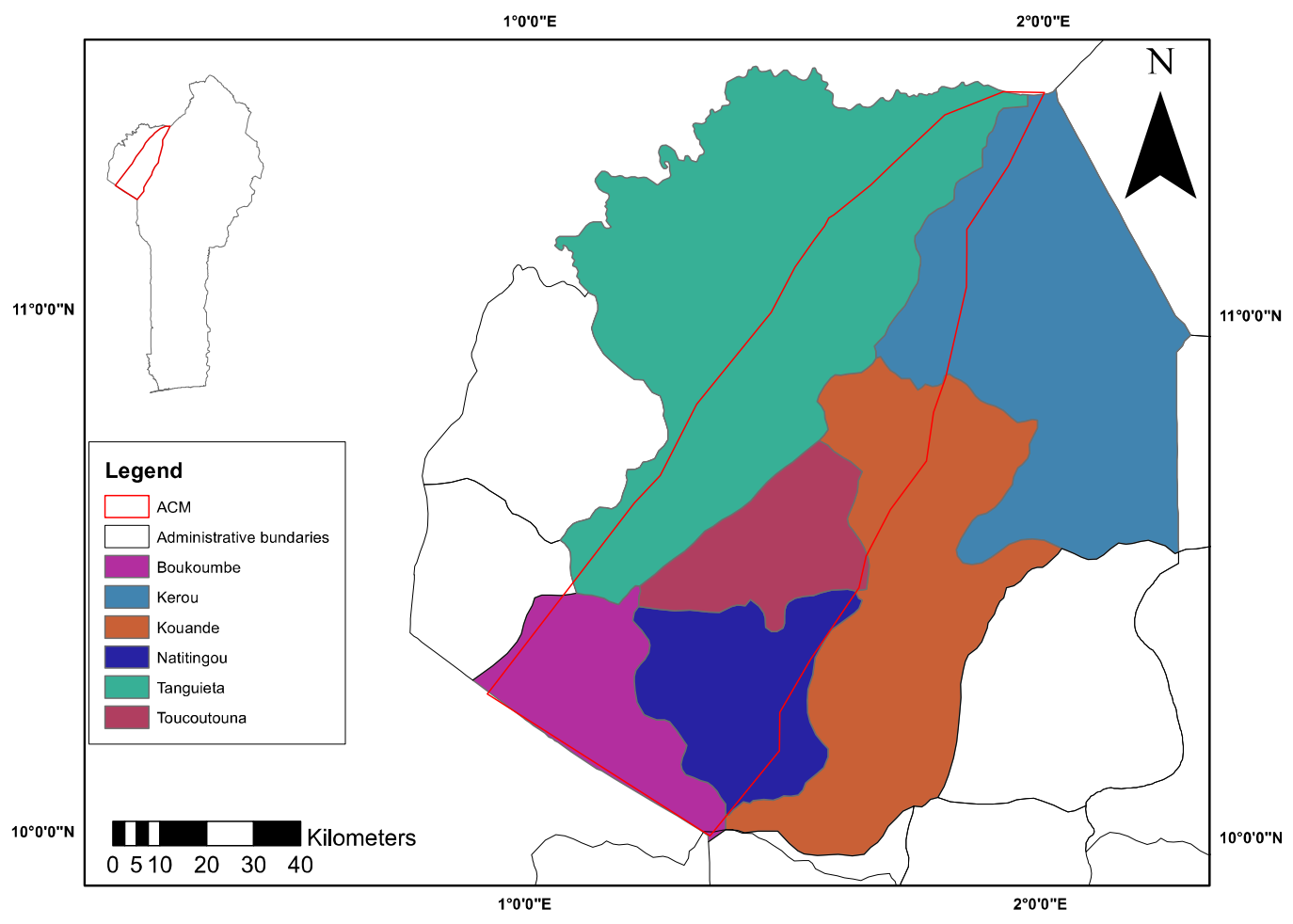

Figure 1: Atacora Chain of Mountains (ACM) in Benin.

\subsection{Land use/land cover change and impact on carbon stocks}

The assessment of land use/land cover change and their impact on carbon stocks in the ACM was carried out through the following steps (Figure 2):

- Data collection: landsat images and ground validation data

- Image processing and classification for land use and land cover classes delineation

- Forest measurements

- Biomass data collection per delineated land cover

\subsubsection{Image Classification}

\subsubsection{Data}

The study used three types of data: Landsat images, ground truth data and tree measurements. Based on the long stretch of the study area, two satellite imageries (scenes 19352 and 193 53) were used to make up the extent of the study area. The Landsat images were downloaded from United States Geological Survey (USGS) Earth Explorer (https://earthexplorer.usgs.gov/) for years 1987, 2001 and 2015. Depending on the availability, the images were downloaded between October and early November to make sure they corresponded to the period of peak biomass in the area. The selection of the images was directed by their quality (cloud-free images were preferred). The ground truth data (315 in total) were collected using Geographical Positioning System (GPS) from March to April 2017 for 2015 image classification and the overall accuracy assessment of the classification results. Tree measurements as described below were carried out to quantify carbon stock in each delineated land cover. 


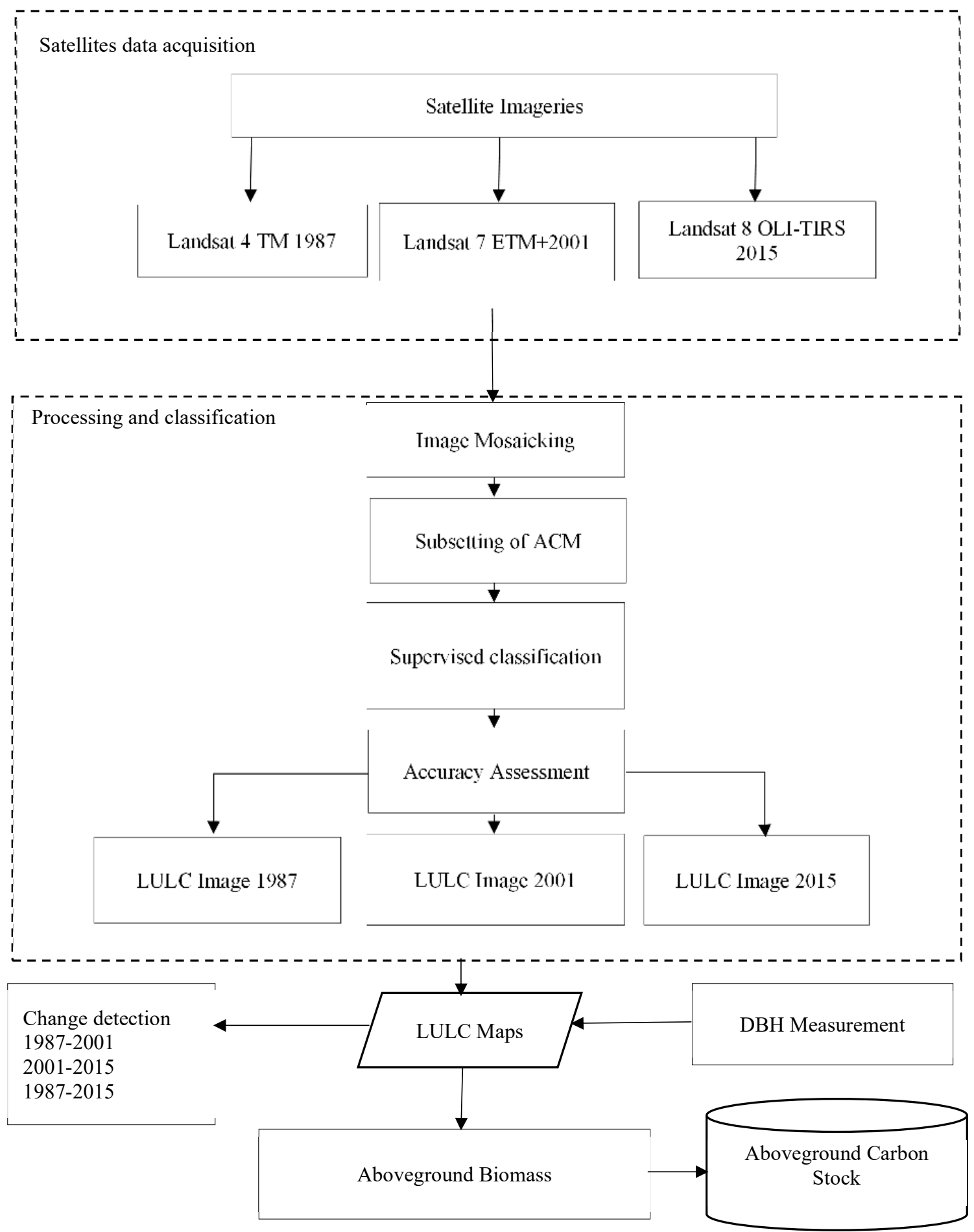

Figure 2: Flowchart showing the main steps of the methodology 


\subsubsection{Images pre-processing and classification}

Data were pre-processed, and classification done in ArcGIS 10.4 (ESRI). Images were mosaicked and the area of interest (AOI) was subsetted out. Supervised classification based on the maximum likelihood algorithm was used to determine the various land use/cover (LULC) classes. Representative samples of each land cover were selected in the image based on ground truth data to build the training areas. Spectral signatures from these training areas were then used by an algorithm to classify the whole image. The classification was done for each year, 1987, 2001 and 2015. Mountainous areas present a mixture of land cover especially herbaceous savanna, fallow lands and shrub savanna. Visual interpretation and the good knowledge of the study area helped to delineate between those land cover classes and reach an acceptable level of classification.

\subsubsection{Accuracy assessment}

The use of accuracy assessment in thematic maps can improve LULC characterization (Adam et al., 2013). The aim of accuracy assessment is to quantitatively assess how effectively the pixels were sampled into the correct land cover classes (Rwanga and Ndambuki, 2017). Two hundred and twenty-nine (229) ground truth points were used to carry out the accuracy assessment. Statistical comparison of reference data and classification results was carried out through error matrix. Kappa statistic (equation1) evaluates the extent of agreement between two raters (Gwet, 2002). A kappa of 1 indicates perfect agreement, whereas a kappa of 0 indicates agreement equivalent to chance.

$$
\text { Kappa }=(\text { Observed accuracy }- \text { chance agreement }) /(1 \text {-chance agreement })
$$

Where: Observed accuracy is determined by diagonal in the error matrix and Chance agreement incorporates offdiagonal (Adam et al., 2013).

\subsubsection{Change detection}

LULC change detection is essential for better understanding of landscape dynamics during a known period of time (Rawat and Kumar, 2015). Areas of observed land cover were computed and compared for 1987, 2001 and 2015 in order to estimate the losses or gains made by each land cover class. Also, analyses were carried out in ArcGIS to determine conversions that have happened over the time. While collecting the ground truth points in the ACM we identified various LULC classes which were categorized as bare lands, settlements, farm lands, savanna, woodland, gallery forests and water (Table 1).

Table 1: Description of the classes identified in the study area

\begin{tabular}{|c|c|}
\hline Land cover class & Description \\
\hline Bare lands & Rocks, bare ground resulting from clearing, burning and erosion \\
\hline Settlements & Villages and towns, roads, commercial infrastructures \\
\hline Farm lands & $\begin{array}{l}\text { Cropping and fallow areas. Common crops in the area include mostly cereals } \\
\text { namely maize (Zea mays), millet (Panicum miliaceum), sorghum (Sorghum } \\
\text { bicolor), rice (Oryza sativa), legumes such as groundnut (Arachishypogaea spp.) } \\
\text { and Bambara beans (Vigna subterranea), soya beans (Glycine max) cowpea } \\
\text { (Vigna unguiculata) and yam (Dioscorea spp.) }\end{array}$ \\
\hline Savanna & $\begin{array}{l}\text { Tree, shrub and grass savanna distributed on slopes and the summits of the range } \\
\text { of mountains. }\end{array}$ \\
\hline Woodland & $\begin{array}{l}\text { Wooded vegetation dominated by trees with open canopy found at the foot of the } \\
\text { range of mountains and the plateau }\end{array}$ \\
\hline Gallery forests & $\begin{array}{l}\text { More or less dense wooded vegetation along waterways in valleys and slopes } \\
\text { (Sinsin and Kampmann, 2010) }\end{array}$ \\
\hline Water & River, lake, bays and non-forested wetlands and ponds. \\
\hline
\end{tabular}




\subsection{Carbon dynamics}

\subsubsection{Aboveground carbon estimation}

Forest inventories were carried out in each delineated land cover class in the study area with a differentiation between tree and shrub savanna. Diameter at breast height $(\mathrm{DBH})$ of all trees with $\mathrm{DBH}>2 \mathrm{~cm}$ were measured and all the herbaceous and other plants were harvested, dried and weighed. Nested plots ( 30 per land cover class) were used whereby tree measurements were done in $10 \mathrm{~m}$ x $10 \mathrm{~m}$ plots, shrub measurement in $5 \mathrm{~m} \times 5 \mathrm{~m}$ plots and grass harvesting in $1 \mathrm{~m} \mathrm{x} 1 \mathrm{~m}$ plots. From these measurements we estimated aboveground biomass and subsequently, aboveground carbon stock. The linear regression approach was used to determine the aboveground biomass at tree level and for each plot. This was based on Chabi's allometric models (Chabi et al., 2016), for aboveground biomass estimation developed in the Dassari Bassin which is also located in northwest Benin and in the same climatic zone, between $10^{\circ} 44^{\prime} 08^{\prime \prime}$ and $10^{\circ} 55^{\prime} 42^{\prime \prime}$ North and $1^{\circ} 01^{\prime} 32^{\prime \prime}$ and $1^{\circ} 11^{\prime} 30^{\prime \prime}$ East. The authors found that all models indicated a high goodness of fit and that while the AICc (corrected Akaike Information Criterion) clearly favored the more complex models, even using only $\mathrm{DBH}$ as a predictor provided a high goodness of fit. In this study, the model with $\mathrm{DBH}$ as predictor (equation 2) and for forest lands, was used.

$$
\ln (A G B)=2.39198+0.111911(D B H)
$$

Chabi (2016), referred to forest lands as land use category that incorporates riparian forest and woodland, savanna woodland and shrub savanna. In this study, carbon stock was determined by multiplying the biomass quantity by 0.5 following Pearson et al., Kanungwe et al. and Faye (Faye, 2016; Kanungwe et al., 2013; Pearson et al., 2005).

\subsubsection{Carbon stocks statistical analyses}

Aboveground carbon stock values were compared across different land cover classes in the study area using bootstrapping confidence intervals in R 3.5.1 (R Core Team, 2018). This method was used because both carbon and transformed carbon data failed to meet the homoscedasticity and normality of residuals assumptions for ANOVA.

\section{Results}

\subsection{Land use/land cover classes and their dynamics in the ACM area}

The overall classification accuracy and the kappa statistic were respectively $80.78 \%$ and 0.78 for the year 2015 used as reference. The results showed that for all the three considered years, the study area was dominated by savanna, covering almost half of the area $(49.1 \%, 46.6 \%$ and $47.7 \%$ for 1987, 2001 and 2015 respectively) (Table 2).

Figure 3 illustrates the changes that occurred during the 28 years of assessment (from 1987 to 2015) for each LULC class. During the period, gallery forests, woodland, water bodies, farm lands and settlements went through remarkable changes (Table 2 and Figure 4). A decrease was noticed in natural vegetation area (gallery forests and woodland) and the water body classes whilst there was an increase in man-made land cover (bare lands, farm lands and settlements). For the first sub-period of 14 years (1987 to 2001), settlement areas increased more than twofold but slowed down in increment during the second half of the period (2001-2015). Farm land areas increased from $12.3 \%$ in 1987 to $18.0 \%$ in 2001 and $18.8 \%$ in 2015 . In 1987, farm lands occupied the third position in area coverage after savanna and woodland. Fourteen years later, farm lands overtook woodland with an increment of $6.5 \%$ in total. During the first 14 years, woodland kept roughly the same coverage $(17 \%)$ but showed a significant decrease in the second period, with a loss of $3 \%$ in 14 years. The situation is even worse with the gallery forests where it was observed for both periods, a decrease of more than half of the area covered $(6.4 \%$ to $2.9 \%$ in the first half and $2.9 \%$ to $1.4 \%$ in the second half). Gallery forests were depleted at a steady rate of more than $50 \%$ during the period. This trend is also observed with the water body class. For the whole period of assessment, savanna decreased by $1.5 \%$ while bare lands and settlements increased by $0.7 \%$ and $3.4 \%$ respectively. 

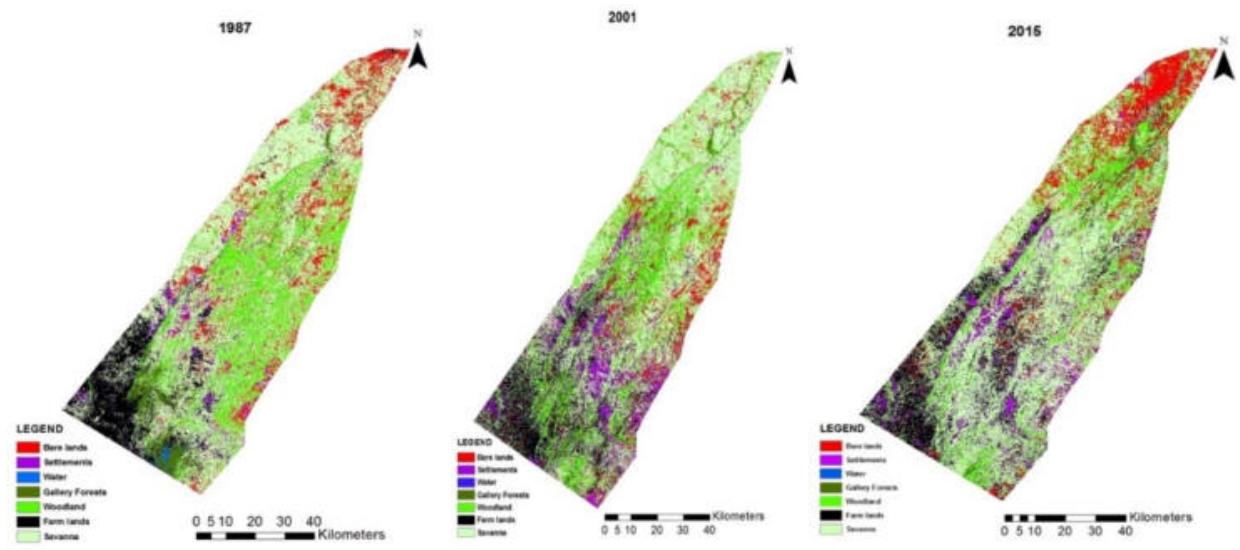

Figure 3: Classified maps of Atacora Chain of Mountains for years 1987, 2001 and 2015

Table 2: Land use/cover classes and proportion during the period of assessment

\begin{tabular}{|c|c|c|c|c|c|c|}
\hline \multirow[t]{2}{*}{ Class name } & \multicolumn{2}{|c|}{1987} & \multicolumn{2}{|c|}{2001} & \multicolumn{2}{|c|}{2015} \\
\hline & $\operatorname{Area}\left(\mathrm{km}^{2}\right)$ & \% Cover & $\operatorname{Area}\left(\mathrm{km}^{2}\right)$ & $\%$ Cover & $\operatorname{Area}\left(\mathrm{km}^{2}\right)$ & \% Cover \\
\hline Bare lands & 736.4 & 10.8 & 595.0 & 8.7 & 785.7 & 11.5 \\
\hline Settlements & 213.1 & 3.1 & 442.3 & 6.5 & 444.2 & 6.5 \\
\hline Water & 36.3 & 0.5 & 12.3 & 0.2 & 9.1 & 0.1 \\
\hline Gallery Forests & 439.3 & 6.4 & 200.2 & 2.9 & 96.7 & 1.4 \\
\hline Woodland & 1204.0 & 17.7 & 1158.1 & 17.0 & 953.8 & 14.0 \\
\hline Farm lands & 836.6 & 12.3 & 1229.8 & 18.0 & 1278.8 & 18.8 \\
\hline Savanna & 3348.8 & 49.1 & 3177.0 & 46.6 & 3246.4 & 47.6 \\
\hline Total & 6814.7 & 100.0 & 6814.7 & 100.0 & 6814.7 & 100.0 \\
\hline
\end{tabular}

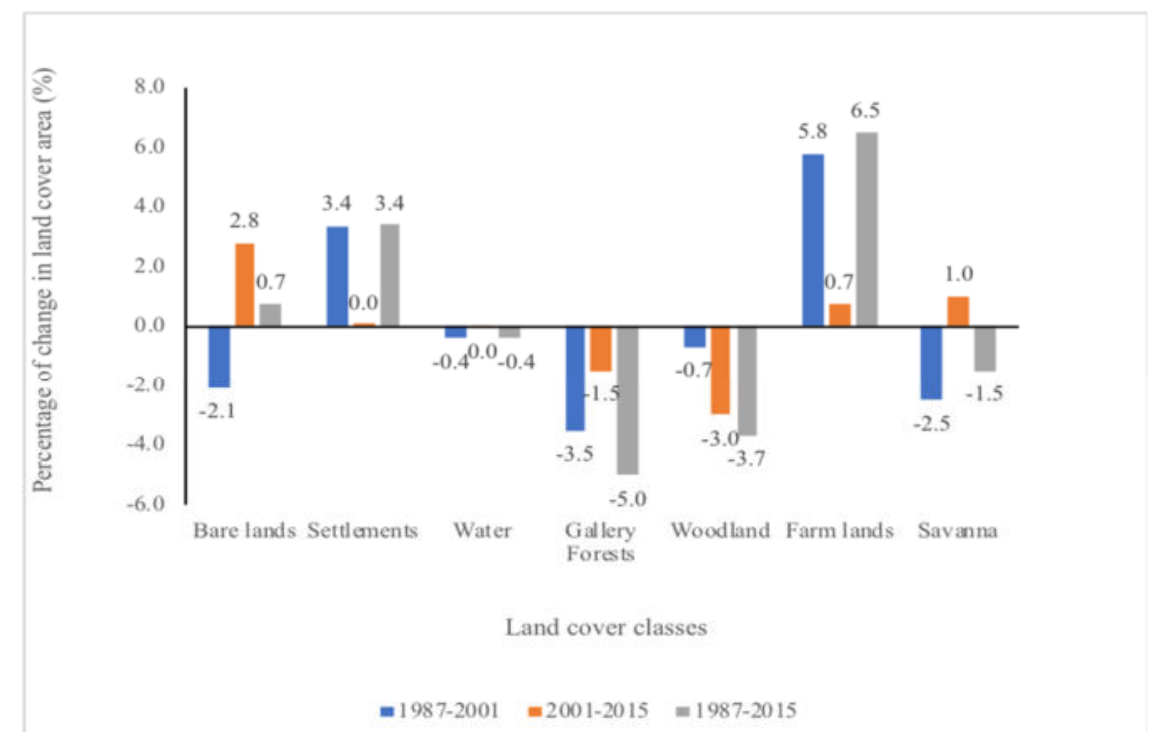

Figure 4: Change in land use/cover expressed as percentage of the total area in the ACM 


\subsection{Land use land cover conversions in the ACM from 1987 to 2015}

The ACM conversion matrix (Table 3) indicates that during the first 14 years of the assessment, there were substantial LULC conversions. Except for farm lands and savanna, all the other LULC classes had more than 50\% of their previous area transformed into other LULC classes. Out of the $213.15 \mathrm{~km}^{2}$ of settlements observed in 1987 , up to $23.91 \%$ were covered by savanna in 2001 . For bare lands, the transition to savanna during the same period was $40.51 \%$ while for farm lands it was $25.42 \%$. In contrast, wooded vegetation namely, gallery forests and woodland changed into less woody land cover; gallery forests changed into woodland and savanna by $31.65 \%$ and $31.06 \%$ respectively whilst woodland changed into savanna by $41.90 \%$. Land cover conversion to farm lands were observed with gallery forests, woodlands, savanna and settlements which lost up to $12.43 \%, 8.13 \%, 14.14 \%$ and $32.09 \%$ respectively of their areas. Only $20 \%$ of the gallery areas in 1987 remained unchanged. Almost half $(48.71 \%)$ of the water was transformed into woodland and $22.52 \%$ into savanna. Generally, during the period 1987 to 2001, farm lands expanded at the expense of savanna, gallery forest and woodland whilst degradation (conversion into less wooded vegetation) affected gallery forests and woodlands. LULC conversion matrix for the second 14-years period (2001 to 2015), indicates remarkable conversion to farm lands and degradation of wooded to less wooded land cover in the ACM. During the period, settlements and bare lands were converted into farm lands by $37.63 \%$ and $16.51 \%$ respectively. The shares of gallery forests, woodland and savanna converted to farm lands were $6.62 \%, 6.08 \%$ and $12.93 \%$ respectively. Woodland and gallery forests got replaced by savanna by $52.71 \%$ and $42.95 \%$ respectively and gallery forests got degraded into woodland by $25.82 \%$. Water class was mostly converted to savanna (16.54\%) and woodland (20.64\%). Nevertheless, up to $38.67 \%$ of farm lands, $26.90 \%$ of settlement and 34.07 of bare lands changed into savanna. Overall, from 1987 to 2015, three primary phenomena were observed with regards to LULC conversions in the ACM. First, there was a conversion of man-made land cover (settlements, bare lands and farm lands) into savanna by $25.51 \%, 26.19 \%$ and $29.13 \%$ respectively. In contrast, natural vegetation namely gallery forest, woodland and savanna were converted into man-made land cover (farm lands) by $8.43 \%, 8.24 \%$ and $15.96 \%$ respectively. Thirdly, during the 28 years of assessment, the ACM went through the degradation of its natural vegetation with gallery forests and woodland being converted into less wooded land cover. Gallery forest shifted into woodland and savanna by $24.09 \%$ and $53.62 \%$ respectively whilst woodland changed into savanna by $59.99 \%$.

\subsection{Carbon stocks and carbon stocks dynamics}

At a landscape level, the satellite images allowed the delineation of three semi-natural vegetation types, namely gallery forests, woodland and savanna. With the ground level inventory, we separated the savanna into tree savanna and shrub savanna thus resulting in four vegetation types. The aboveground carbon stock comparisons were then made for the four vegetation types (Table 4). The aboveground carbon stock's confidence intervals of gallery forests, woodlands and tree savanna overlap, which means that there is no significant difference between the carbon stored by these land cover classes. In contrast, the aboveground carbon stock's confidence interval of shrub savanna does not overlap with any of the three other vegetation types. There is then a significant difference between aboveground carbon stock in shrub savanna and the other three vegetation types. The mean carbon stock for this land cover class is $17.67 \mathrm{t} / \mathrm{ha}$ whilst gallery forest, woodland and tree savanna have means of 57.78, 42.07 and $31.59 \mathrm{t} /$ ha respectively. 
Table 3: Land use land cover conversion matrix in the ACM from 1987 to 2015

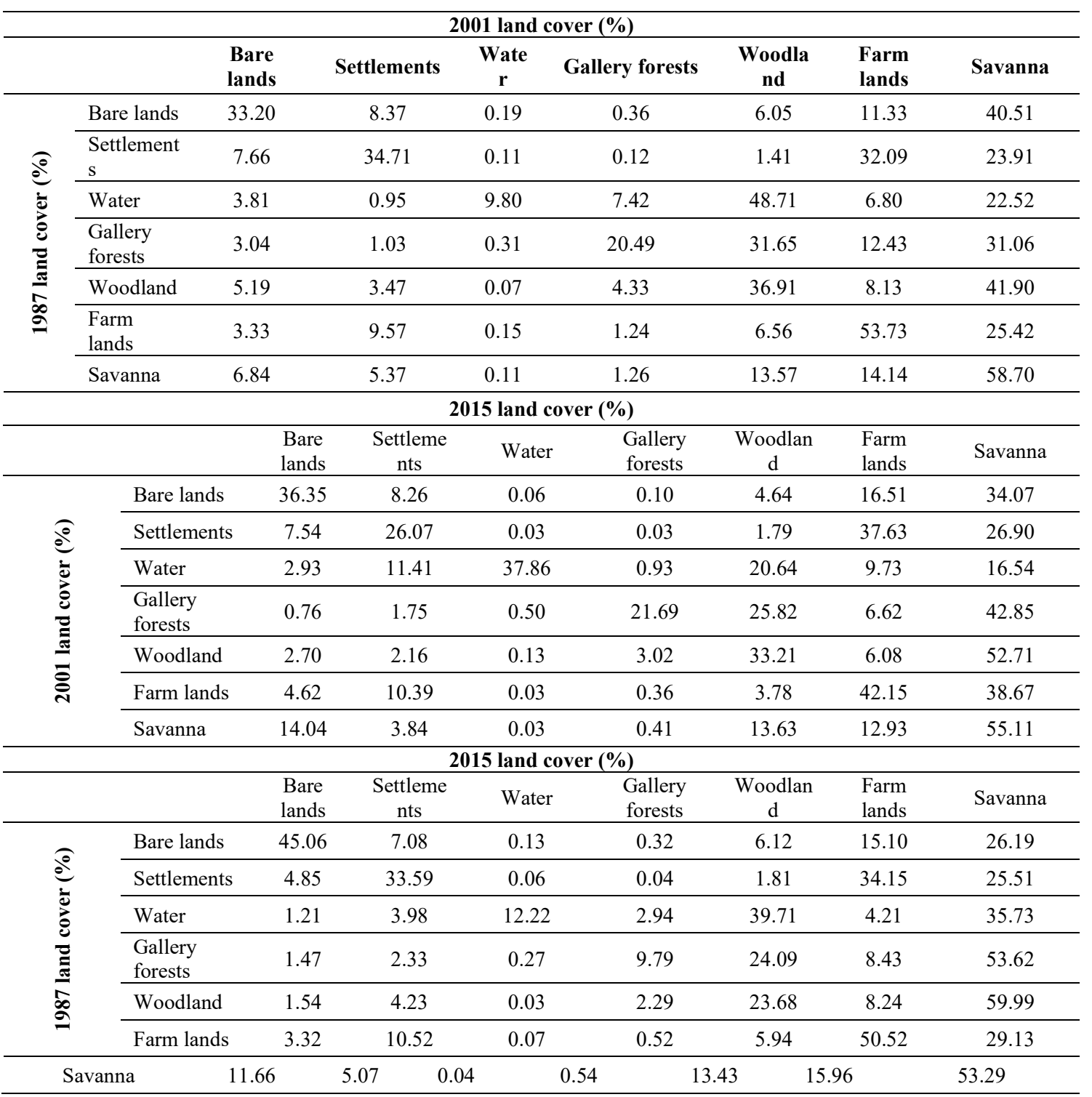

Table 4: Comparison of aboveground carbon stock in the land cover classes through $95.00 \%$ bias-corrected-and-

\begin{tabular}{lccccc}
\multicolumn{7}{c}{ Land cover class } & $\begin{array}{l}\text { Mean } \\
\text { (t/ha) }\end{array}$ & CI(Low) & CI (High) & bias & SE \\
\hline Gallery Forests & $57.785(\mathrm{a})$ & 36.791 & 135.871 & -0.038 & 18.061 \\
\hline Shrub Savanna & $17.668(\mathrm{~b})$ & 14.857 & 19.880 & 0.004 & 1.251 \\
\hline Tree Savanna & $31.585(\mathrm{a})$ & 26.355 & 38.130 & -0.045 & 2.939 \\
\hline Woodland & $42.074(\mathrm{a})$ & 35.000 & 50.650 & 0.088 & 3.911 \\
\hline
\end{tabular}

Vegetation types with the same letter are in the same group. The bias is the difference between the mean of the resamples and the mean of the original sample; "SE" is the standard error - that is, the standard deviation of the resampled means.

Based on LULC classification results (Table 2), the carbon stored in each land cover was calculated with the assumption that biomass at the date of the forest measurements was the same in previous years. The equivalent 
aboveground carbon per land cover class for each Based on LULC classification results (Table 2), the carbon stored in each land cover was calculated with the assumption that biomass at the date of the forest measurements was the same in previous years. The equivalent aboveground carbon per land cover class for each year after the losses and gains were determined and the dynamics deducted. Because results from remote sensing classification did not differentiate tree savanna from shrub savanna, we used the mean carbon stock between tree savanna and shrub savanna as the mean carbon stock in the delineated savanna.

In all the three analyzed years, savanna stored the highest quantity of aboveground carbon, followed by woodland and gallery forests. In $1987,61.86 \%$ of the total carbon stored in the natural vegetation was in savanna whilst woodland stored $25.41 \%$ and gallery forests stored $12.73 \%$. In 2001, the loss of gallery areas of 3.5\% (Figure 4), from 1987 to 2001 , caused an estimated equivalent loss in carbon of $6.2 \%$ (from $12.73 \%$ to $6.53 \%$ ) of the total stored in the three natural land cover classes.

Even though in the first period there was an increase in percentage of carbon stored in woodland in relation to the total of the year, Figure 5 and Table 5 show that there was actually a decrease in the absolute total aboveground carbon stored in this land cover. The same situation was observed with savanna where the actual increase in absolute aboveground carbon stock in the land cover was only in the second period and still lower than the value in 1987. Overall, from 1987 to 2015 aboveground carbon stored in gallery forests, woodlands and savanna decreased, causing a general decrease of the aboveground carbon stored in the semi-natural vegetation types (Figure 5). There was then an estimated release of $17.10 \%$ of carbon in the three land cover classes for the 28 years of assessment.

Table 5: Total and percentage aboveground carbon in delineated land cover in the ACM.

\begin{tabular}{cccccccc} 
& \multicolumn{2}{c}{ Gallery Forests } & \multicolumn{2}{c}{ Woodland } & & \multicolumn{2}{c}{ Savanna } \\
\hline & $\begin{array}{c}\text { Total aboveground } \\
\text { carbon }\end{array}$ & $\%$ & $\begin{array}{c}\text { Total aboveground } \\
\text { carbon }\end{array}$ & $\%$ & $\begin{array}{c}\text { Total aboveground } \\
\text { carbon }\end{array}$ & $\%$ \\
\hline 1987 & 2538577.68 & 12.73 & 5065778.60 & 25.41 & 12333420.24 & 61.86 \\
\hline 2001 & 1156884.59 & 6.53 & 4872390.09 & 27.48 & 11700665.86 & 65.99 \\
\hline 2015 & 558492.60 & 3.38 & 4013007.60 & 24.28 & 11956225.76 & 72.34 \\
\hline
\end{tabular}

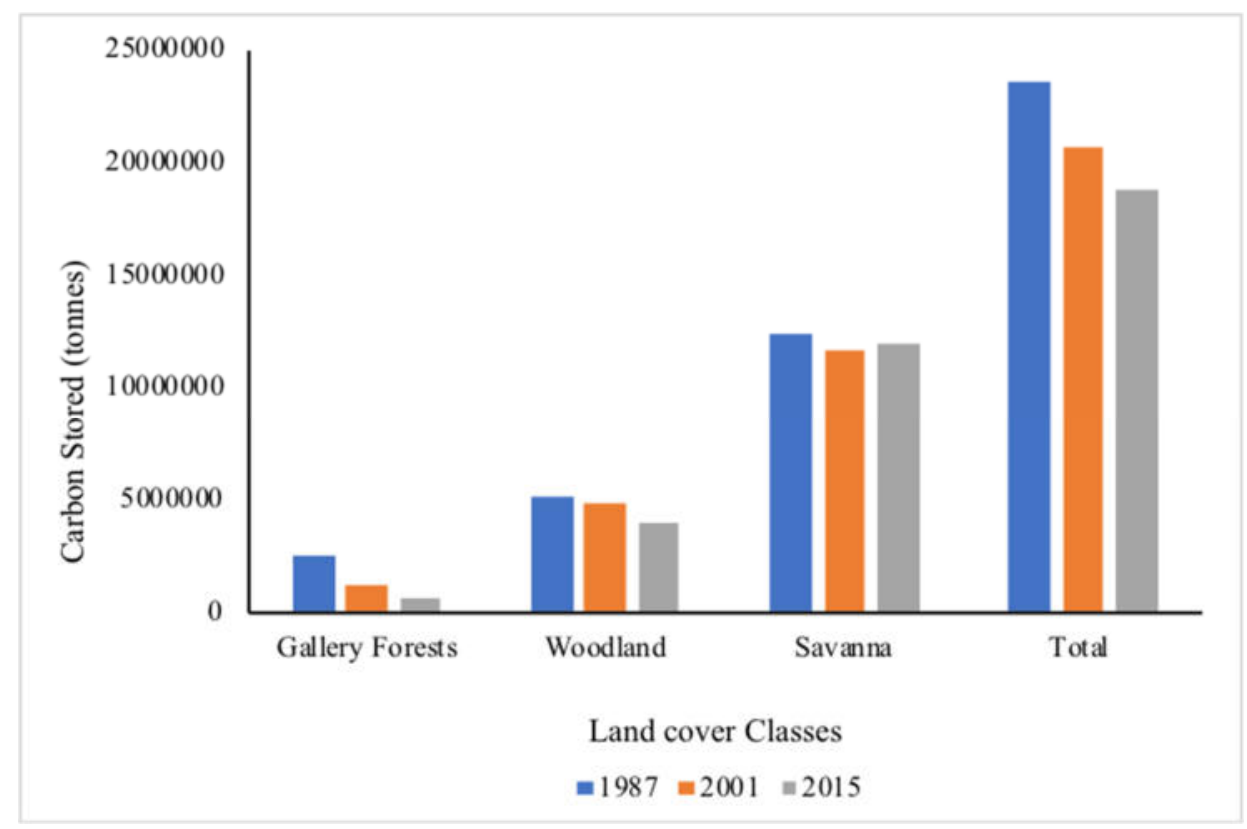

Figure 5: Aboveground carbon dynamics for each sub-period and during the entire period of assessment. 


\section{Discussion}

\subsection{Land use land cover changes in the overall ACM from 1987 to 2015}

This study delineated seven classes of LULC: bare lands, settlements, gallery forests, woodland, savanna, farm lands and water. Previous studies in the same area (Agbanou et al., 2018; Sinsin and Kampmann, 2010), however revealed eight classes of LULC. Our study showed a smaller number of semi-natural vegetation types because the mosaics considered by the other studies, particularly savanna, were grouped into one class by our study. During the 28 years of assessment, savanna land cover dominated the study area covering almost half of the whole area. In 1987, woodlands were second after savanna and before farm lands and bare lands. At the end of the study period (2015), farm lands became next to savanna in expanse. There was a substantial loss in the share of natural vegetation such as gallery forests and woodland whilst farm lands, settlements and bare lands gained in their area coverage. These results were also found by Agbanou et al. (Agbanou et al., 2018), who showed that the landscape on a portion of the same area, initially dominated by open wooded forests and wooded and shrub savannas in 1987 was replaced in 2016 by land use categories including crop and fallow mosaics. An assessment of LULC and trends in Benin by the USGS (USGS, 2016a), showed that from 1975 to 2013, there was a remarkable expansion of agricultural lands across most Benin regions and a substantial decrease in dense forests (58\%) and woodland $(70 \%)$. Similar patterns of land use trend over the time were described in other West African countries. These include studies in southern Burkina Faso (Ouedraogo et al., 2010), western Senegal, (Sambou et al., 2015) and south-eastern Senegal (Faye et al., 2016). A study carried out by USGS (USGS, 2016b) in a 38-year period (1975 to 2013) showed that the fastest average annual rate of cropland expansion in West Africa were found in Togo, Benin, Chad, Mauritania and Burkina Faso and in every country of the same region, agriculture was exerting pressure on the natural landscapes, replacing fragmented savanna, woodland and forests.

From 1987 to 2015 , there was a shift from wooded to less wooded natural vegetation: woodland and gallery forests shifted into savanna and gallery forests shifted to woodland too. Also, some natural vegetation and settlement areas shifted into farm lands. Overall, the conversion follows three main patterns: 1) the change from man-made land cover into natural vegetation, 2) the other way around (natural vegetation to man-made land cover). The net effect was a reduction in natural vegetation cover. Thirdly, there was a degradation process marked by the substantial transformation of woodlands and gallery forests after 28 years into less wooded land cover. The conversion of settlements, bare lands and farm lands to savanna suggests there may have been a departure of people from some areas, abandoning their lands which then turned into savanna. People leave areas with decreasing soil fertility (conversion of settlements, farm lands and bare lands into savanna) for areas with better potential (conversion of natural vegetation into farm lands and settlements). Indeed, the soils in the ACM area are ferruginous, shallow and gravelly with low fertility levels causing farmers to look for new lands either in the same area or even in other places of the country known to have better soil fertility. Assessing LULC change on the Binah River watershed (Togo and Benin) Badjana et al. (Badjana et al., 2015) explained that the observed conversion of agricultural land to savanna at each time period was likely due to the shifting between cultivation and fallow systems, which is common in the region. The abandonment of former cultivated lands for new areas is a well-known practice in many parts of the tropics (Ickowitz, 2006) and constitutes an important component of land use dynamics in rural areas. Using visual interpretation with Landsat images Heinimann et al. (Heinimann et al., 2017), demonstrated that, despite decreases in its extent over the last four or five decades, shifting cultivation remains widespread with the largest share observed in Africa. The observed loss of the water class may be explained by two hypotheses. Firstly, they could be a drying up of water bodies in the study area as a consequence of climate change. According to Boko et al. (Boko et al., 2012), from 1951 to 2010, there was a rainfall decrease of 11 to $28 \%$ in the area, which when occurring for several consecutive years may cause the drying up of some water bodies. Secondly, the reduction in gallery forest areas as observed in the study is associated with many processes such as destabilization of river banks and siltation that promote drying up of water. After the water has dried up the land can be either cultivated or covered by other vegetation through succession which may evolve into other land cover classes over the time.

\subsection{Aboveground carbon dynamics}

The observed values of aboveground carbon stocks per land cover are similar to those found by Chabi (2016), in the same ecological zone in Benin except for gallery forest where our mean aboveground carbon stock is lower. The lower values of gallery forests may be due to the fact that gallery forests are degraded and highly variable as per the results from land cover conversion in the ACM. This is also evidenced by the confidence interval of this vegetation type that covers a large range of values meaning that aboveground carbon variability in this land cover is high. The actual mean can be anywhere between 36.79 and $135.871 \mathrm{t} / \mathrm{ha}$. The amount of carbon in semi-natural vegetation such as gallery forests, woodlands and savanna, attest to the fact that the range of mountains and its 
surrounding areas have a high potential to store carbon and play an important role in climate change mitigation in Benin.

Comparing the area change of the various LULC classes with their relative change in carbon stocks, one finds that the gains and relative lower losses in cover by savanna does not affect the total carbon stocks whilst in the case of woodland and gallery forests reduction in area results in remarkable reduction in carbon stocks. The reason is that the quantity of carbon stored per unit area in the gallery forests and woodland are significantly higher than the one in savanna. Again, the conversion of bare areas, settlements and agricultural lands into savanna does not occur with any appreciable amount of aboveground carbon built up, thus adding little if any carbon stocks to the vegetation. Therefore, if gallery forests, woodland and tree savanna are progressively transformed into shrub savanna (the observed trend), there will be a progressive decrease in carbon stock in the ACM and implicitly increasing carbon emission.

In the ACM, the clearing up of wooded vegetation for agriculture (i.e., deforestation) was less important for carbon stocks dynamics than the conversion of wooded into less wooded vegetation (i.e., forest/woodland degradation). This means to reduce carbon emission there will be the need to strengthen anti-forest degradation measures in the landscape.

\section{Conclusions}

From 1987 to 2015, all semi-natural land cover classes were converted into man-made land cover with higher losses in gallery forests, followed by woodlands and savanna. Subsequently, man-made land cover expanded at noticeable rates. The largest expansion occurred with farm lands followed by settlements and bare lands. The aboveground carbon stock in the semi-natural land cover decreased in the ACM at a rate of $17.10 \%$ in 28 years as a result of semi-natural land cover conversion. Wooded vegetation in the ACM contains appreciable quantity of aboveground carbon and if they are well-preserved they may play an important role in climate change mitigation. Considering the amount of aboveground carbon stored in wooded vegetation and the level of degradation that affect them, there is a need to investigate the drivers of these degradation in the study area for the ACM conservation.

\section{References}

Adam, A.H.M., A.M.H, E., Salih, M, A.., 2013. Accuracy assessment of land use and land cover Classification "case study of Shomadi area- Renk County-Upper Nile State, South Sudan.” Int. J. Sci. Res. Publ. 3, 1-6.

Agbanou, T., Paedelow, M., Ismaïla, T.I., Tente Brice, 2018. Modelisation des Changements d'occupation des terres en region Soudanienne $\mathrm{Au}$ Nord-Ouest $\mathrm{Du}$ Benin. Eur. Sci. J. 14. https://doi.org/10.19044/esj.2018.v14n12p248

Alweny, S., Nsengiyumva, P., Gatarabirwa, W., 2014. Africa Sustainable Mountain Development Technical Report No. 1, ARCOS, October 2014. Kampala (Uganda) and Cambridge (UK).

Avohou, H.T., Sinsin, B., 2009. The Effects of Topographic Factors on Aboveground Biomass Production of Grasslands in the Atacora Mountains in Northwestern Benin. Mt. Res. Dev. 29, $250-254$. https://doi.org/10.1659/mrd.00028

Badjana, H.M., Helmschrot, J., Wala, K., Flügel, W.-A., Afouda, A., Akpagana, K., 2015. Land cover changes assessment using object-based image analysis in the Binah River watershed (Togo and Benin). Earth Sp. Sci. 2, 403-416. https://doi.org/10.1002/2014EA000083.Received

Boko, M., Kosmowski, F., Vissin, E.W., 2012. Les enjeux du changement climatique au Bénin. https://doi.org/10.13140/RG.2.1.2825.4808

Chabi, A., 2016. Land-use change modelling, scenario development and impact assessment on CO2 and N2O emission from vegetation degradation in the Dassari basin, Benin. KWAME NKRUMAH UNIVERSITY OF SCIENCE AND TECHNOLOGY, KUMASI, GHANA LAND-USE.

Chabi, A., Lautenbach, S., Orekan, V.O.A., Kyei-Baffour, N., 2016. Allometric models and aboveground biomass stocks of a West African Sudan Savannah watershed in Benin. Carbon Balance Manag. 11. https://doi.org/10.1186/s13021-016-0058-5

Chape, S., Jenkins, M., Spalding, M., 2008. The world's protected areas : status, values and prospects in the $21 \mathrm{st}$ Century. UNEP-WCMC.

FAO, 2011. Why invest in sustainable mountain development? Food and Agriculture Organization of the Unites Nations, Rome. Rome.

FAO, 2000. International year of mountains: concept paper, Food and Agriculture Organization of the United 


\section{Nations Rome.}

FAO, Partnership, S.M., UNCCD, SDC, CDE, 2011. Highlands and Drylands - Mountains, a source of resilience in arid regions. Published by FAO, UNCCD, Mountain Partnership, Swiss Agency for Development and Cooperation, and $\mathrm{CDE}$, with the support of an international group of experts. Rome.

Faye, L.C., 2016. Impacts of community-forest management on land use change, vegetation dynamics and carbon stocks in South-Eastern Senegal. PhD thesis, Kwame Nkrumah University of Science and Technology, Kumasi, Ghana.

Faye, L.C., Sambou, H., Kyereh, B., Sambou, B., 2016. Land Use and Land Cover Change in a CommunityManaged Forest in South-Eastern Senegal Under a Formal Forest Management Regime. Am. J. Environ. Prot. 2016; 5, 1-10. https://doi.org/10.11648/j.ajep.20160501.11

Gwet, K., 2002. Kappa Statistic is not Satisfactory for Assessing the Extent of Agreement Between Raters. Stat. Methods Inter-Rater Reliab. Assess. 1-5.

Heinimann, A., Mertz, O., Frolking, S., Christensen, A.E., Hurni, K., Sedano, F., Chini, L.P., Sahajpal, R., Hansen, M., Hurtt, G., 2017. A global view of shifting cultivation : Recent , current, and future extent. PLoS One 12, $1-21$.

Ickowitz, A., 2006. Shifting Cultivation and Deforestation in Tropical Africa : Critical Reflections. Dev. Change 37, 599-626.

INSAE, 2018. Synthèse des principaux résultats du RGPH-4 de l'Atacora, Institut National de la Statistique et de l'Analyse Economique.

INSAE, 2004. Cahier des villages et quartiers de ville Département de 1'ATACORA. Institut National de la Statistique et de l'Analyse Economique Cahier, Cotonou.

Kanungwe, F., Helen, C., John, A., Vinya, R., 2013. Forest Ecology and Management Floristic composition , species diversity and carbon storage in charcoal and agriculture fallows and management implications in Miombo woodlands of Zambia. For. Ecol. Manage. 304, 99-109. https://doi.org/10.1016/j.foreco.2013.04.024

Korner, C., Ohsawa, M., 2006. Mountains Systems, in: R. Hassan, R. Scholes, and N.A. (Ed.), Ecosystems and Human Well-Being: Current State and Trends. Island Press, Washington, DC, pp. 1993-1996.

Korner, C., Ohsawa, M., 2005. Mountain Systems, in: Ecosystems and HumanWell-Being: Current State and Trends. pp. 683-716.

MEA, 2005. The Millennium Ecosystem Assessment. Ecosystems and Human Well-being: Synthesis. Washington, DC. https://doi.org/10.1196/annals.1439.003

Ouedraogo, I., Tigabu, M., Savadogo, P., Compaoré, H., Odén, P.C., Ouadba, J.M., 2010. Land cover change and its relation with population dynamics in Burkina Faso, West Africa. L. Degrad. Dev. 21, 453-462. https://doi.org/10.1002/ldr.981

Pearson, T., Walker, S., Brown, S., 2005. Sourcebook for land use, land-use change and forestry projects. Winrock International.

R Core Team, 2018. R: A language and environment for statistical computing. R Foundation for Statistical Computing, Vienna, Austria. URL https://www.R-project.org/.

Rawat, J.S., Kumar, M., 2015. Monitoring land use / cover change using remote sensing and GIS techniques : A case study of Hawalbagh block, district Almora, Uttarakhand, India. Egypt. J. Remote Sens. Sp. Sci. 18, 77-84. https://doi.org/10.1016/j.ejrs.2015.02.002

Rwanga, S.S., Ndambuki, J.M., 2017. Accuracy Assessment of Land Use / Land Cover Classification Using Remote Sensing and GIS. Int. J. Geosci. 8, 611-622. https://doi.org/10.4236/ijg.2017.84033

Sambou, S., Lykke, A.M., Sambou, H., Guiro, I., Sambou, B., Mbow, C., 2015. Land Use-Land Cover Change and Drivers of Deforestation in the Patako Protected Area (Center-West of Senegal). Am. J. Environ. Prot. 4, 306-317. https://doi.org/10.11648/j.ajep.20150406.17

Sinsin, B., Kampmann, D., 2010. Biodiversity Atlas of West Africa volume I Bénin. Benin. Cotonou \& Frankfurt/Main.

Spehn, E.M., Rudmann-Maurer, K., Körner, C., D, M., 2010. Global Mountain Biodiversity Assesment (GMBA) of DIVERSITAS,Basel. GMBA-DIVERSITAS, Basel. https://doi.org/10.1016/j.cca.2007.05.017

UNCED, 1992. United Nations Conference on Environment \& Development Rio de Janerio, Brazil, 3 to 14 June 1992, AGENDA 21. https://doi.org/10.1007/s11671-008-9208-3

USGS, 2016a. Land Use, Land Cover and Trends in Benin [WWW Document]. USGS. URL https://landcovertrends.usgs.gov/main/about.html (accessed 5.16.18).

USGS, 2016b. Land Use and Land Cover in West Africa [WWW Document]. USGS. URL https://www.mendeley.com/reference-management/web-importer 
Wala, K., Sinsin, B., 2010. La chaîne de l'Atacora, in: Sinsin, B., Kampmann, D. (Eds.), Atlas de La Biodiversité de 1 'Afrique de l'Ouest Tome 1. Bénin, pp. 576-587. 